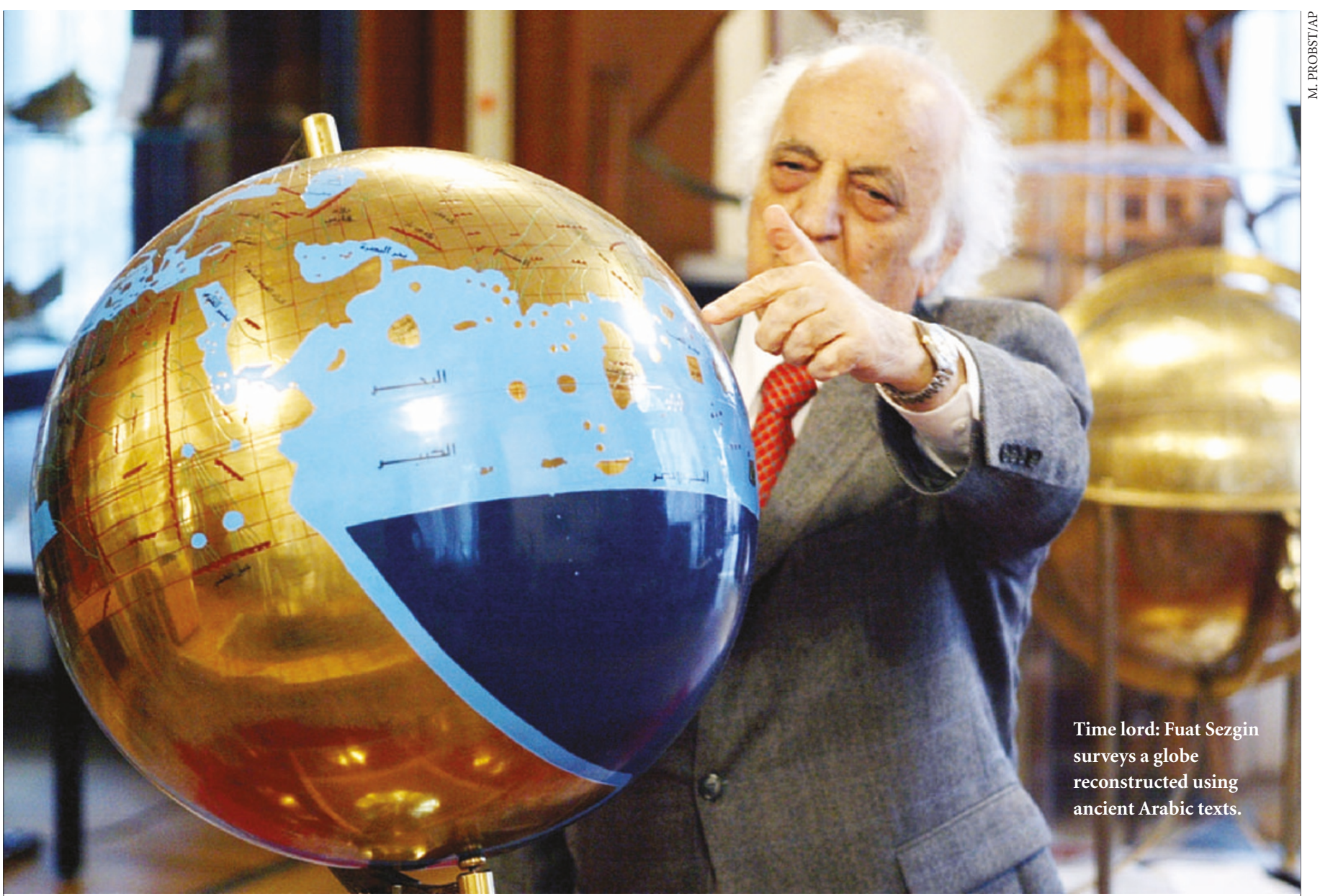

\title{
Rebuilding the past
}

\section{Western science owes much to Islam's golden age - a debt that is often forgotten. To help redress the balance, Fuat Sezgin has reconstructed a host of scientific treasures using ancient Arabic texts. Alison Abbott reports.}

$\mathrm{F}$ ew passers-by in this leafy German suburb realize that the wonders of medieval Islam are just a few steps away. But those who enter Frankfurt's Institute for the History of Arabic-Islamic Science find themselves among the wonders of the historic Middle East. Fuat Sezgin, professor emeritus of the history of science at the University of Frankfurt, guides his guests through a labyrinth of tiled and mirrored rooms to the white-walled chambers of an exquisite yet little-known museum.

And there it is: an Aladdin's cave of science treasures. Each one has been recreated, thanks to Sezgin's labours, from descriptions in ancient texts of the Arab world. Some 800 newly built instruments — from ornate astrolabes to complex water clocks - are on display within the museum's 13 rooms.

Sezgin's long academic life has been quietly dedicated to retrieving Arabic science history. Now, with his eightieth birthday just behind him, he is keen to exhibit his life's work to the public. He says he wants to both remind the West of its debt to the ancient Islamic world, and raise Arabs' pride in their past achievements.

Western science historians know very well that the Arab world was the guardian of the ancient Greeks' scientific knowledge during the Middle Ages, before the European Renaissance rediscovered and extended it. But they also acknowledge that there has been too little study of how the Arabs developed and used that knowledge, and how it fed Europe's cultural revival. "It has been a bit of a blind spot," says Peter Damerow of the Max Planck Institute for the History of Science in Berlin, "mostly because it demands such language skills.”

In his youth, Sezgin trained under the sternest of taskmasters in his home town of Istanbul - the orientalist Hellmut Ritter, who insisted that his students learn a new language every year. Thanks to such discipline, Sezgin is one of a small number of experts who has few linguistic problems with manuscripts written in Babylonian, Greek, Latin or Persian — in addition to Arabic.

\section{Text messages}

By the sixth century AD the scientific traditions of Ancient Greece had largely petered out, but the Greeks left behind important scientific and philosophical texts. For two centuries between 750 and 950, the caliphs of the Abbasid dynasty, centred in Baghdad, supported a mammoth translation effort. Greek works translated into Arabic include Euclid's geometry, Ptolemy's astronomy, the medical works of Galen and Hippocrates and the pharmacopoeia of Dioscorides.

The caliphs understood the importance of scholarship to their expanding empire. As the reach of the Islamic world spread, stretching from northern India to Spain, they absorbed 
as much knowledge as they could from each conquest. In Persia and India, unlike Greece, the scientific traditions were still very much alive. And so it was to Persian and Indian scholars that the translators turned when they needed to make scientific, as well as linguistic, sense of the old Greek manuscripts.

Such expertise was vital because the caliphs wanted their acquired knowledge to deliver practical as well as intellectual benefits to their empire: from monumental architecture and city planning to medical care and transport. Luckily for Sezgin, this means that many texts written by Arab scholars include detailed engineering information on how to build mechanical devices, scientific instruments or architectural components.

In the fifteenth century, the Islamic world shrank under military pressure from western Europe - the last Muslim forces were forced out of Spain in 1492, the year Christopher Columbus reached America. By this time, the European Renaissance was under way and Islamic knowledge was sucked up by powers on the rise, such as Spain and France. Many Arabic works had by then been translated into Latin, but the sources themselves were neglected. Although European libraries and museums collected Arabic scripts, they sat in obscurity as they were largely indecipherable. Over time these trophies of ancient Islam were taken even farther afield to Russia and the United States.

\section{Paper trail}

The European Renaissance's debt to Islamic science has never been entirely forgotten, but there has been little systematic analysis. Sezgin is one of the few contemporary champions of the field. He spent more than three decades travelling the world seeking out 'lost' manuscripts, copying them and interpreting them. He tracked down some in countries formerly under Islamic rule, particularly India - which Sezgin estimates to have 50,000 such manuscripts.

His odyssey led to a 12-volume academic work, Geschichte des arabischen Schrifttums (History of Arabic Literature). Then, about 30 years ago, he decided to begin reconstructing the instruments he had read about. "Sadly, few had survived the centuries," says Sezgin.

His first reconstruction was a model of a horse-drawn ratcheted wheel to raise water from wells, built by the workshop at the University of Frankfurt, where Sezgin was appointed professor in 1966. It had been described in a book dating to about AD 1200 by Ibn al-Razzāz al-Jazarī. As his enthusiasm deepened, Sezgin found himself casting far afield for craftsmen who could help reconstruct more complex instruments. The drawings of figures and pictures on a 1044 celestial globe were done in Bremen, but the

\section{Jumbo timepiece}

This 8-foot-high reconstruction of wood and brass keeps time perfectly, as Fuat Sezgin is happy to demonstrate. Inside a water-filled bucket, hidden within the elephant's body, floats a deep bowl with a small hole in its centre. The water leaks through the hole slowly, taking exactly 30 minutes to fill the bowl enough so that it sinks. As it does so, it pulls on a string attached to a 'see-saw' in the tower on the elephant's back, and the rest of the clock springs into action.

First, the see-saw releases a ball from the tower that falls into the mouth of one of the snakes. Under the weight, the snake tips forward and, through a system of strings, the figure in the tower raises his right or left hand to indicate the full or half hour, while another figure strikes his drum. Then, as the snakes' tails rise, the sunken bowl is hauled up to start the cycle all over again.

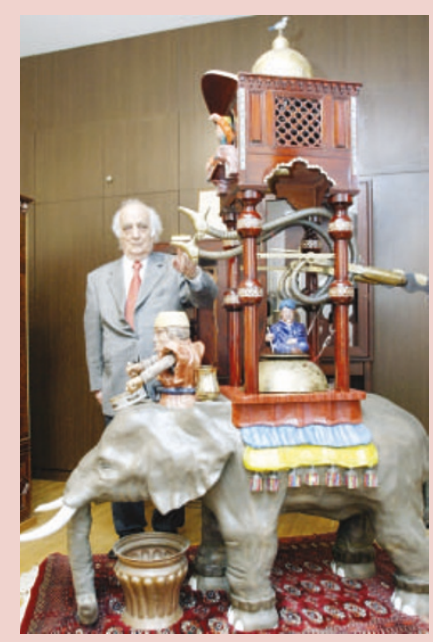

fine engraving, with the accompanying script, was done in Cairo.

Some of the items in his collection are fairly simple - the diverse surgical scalpels and cauterizing instruments, for example. But others, including astronomical instruments, are extraordinarily complex. Some of the most dramatic are enormous, intricate clocks that use water to measure time. Sezgin is particularly proud of an elaborate water clock described by al-Jazarī in about 1200 (see'Jumbo timepiece', above).

Sezgin is most animated when talking about ancient Arabic geographical and nautical scholars. But there are no true disciplinary borders to his pride. He beams just as broadly on recalling his discovery of manuscripts describing astronomical instruments used in tenth-century Islamic observatories - some six centuries before they were used in Europe.

And he gaily reassures visitors recoiling from his gruesome surgical instruments that "the old Arab world had general anaesthetics — morphine-based". He describes his collections of sophisticated Islamic weaponry, and the equally sophisticated distilleries for rose water, with ebullient pleasure. The museum also includes a major collection of original Islamic musical instruments, assembled by Sezgin's colleague Eckhard Neubauer.

Descriptions of the al-Jazarī - Fuat Sezgin

were accompanied by detailed water clock were accomps. But other equipment was harder to reconstruct. For example, the advanced compass that a Portuguese sailor came across while sailing the Indian Ocean was reconstructed from a description by a sixteenthcentury historian. "It was not necessarily much harder to reconstruct without pictures, but it always required a lot of reading of the text to be sure we had understood exactly," says Sezgin.

Whatever the challenge, Sezgin rose to it, sparing no time, trouble or money. He has always used materials that would have been used at the time - heavy woods, brass, even gold when called for. When he retired, Sezgin created a foundation to raise money for the museum. But he has thrown his own money in too, saying that he lives as modestly as he can: "I don't have many personal needs." His total investment in the collection is well above $€ 2$ million (US\$2.7 million), he estimates, not including travel costs. How much might it be worth on the open market? "Maybe $€ 50$ million," says Sezgin, with a delighted laugh at the absurd thought that he could let it go at any price.

\section{Hidden treasures}

Despite its dimensions and diversity, the collection remains, even among scholars, almost unknown. Sezgin has chosen to be a loner in his venture. But this year, for the first time, he allowed a few small exhibitions to take place. Some of the instruments were shown at the Topkapi Palace Museum in Istanbul and at the Jewish Museum in Frankfurt. And there is now a virtual museum in German on the Internet.

Scholars who haven't seen the museum are intrigued. "Having physical instruments can be helpful in getting people to understand what they cannot read because of the language issue," says John Heilbron, a science historian at Worcester College, Oxford, UK. And even for those who can read the texts, says Damerow, “it's hard to know just how easy an instrument might have been to use, and how precise it may be in its measurements - it really helps to have it in your hand".

These scholars, and the wider public, may not have to wait much longer to see Sezgin's treasures up close. The first major exhibition of the collection is planned for spring 2006 at the Arab World Institute in Paris. Sezgin is finally opening his museum doors to the future, as well as to the past.

Alison Abbott is Nature's senior European correspondent. http://web.uni-frankfurt.de/fb13/igaiw/ museum/museum.html 